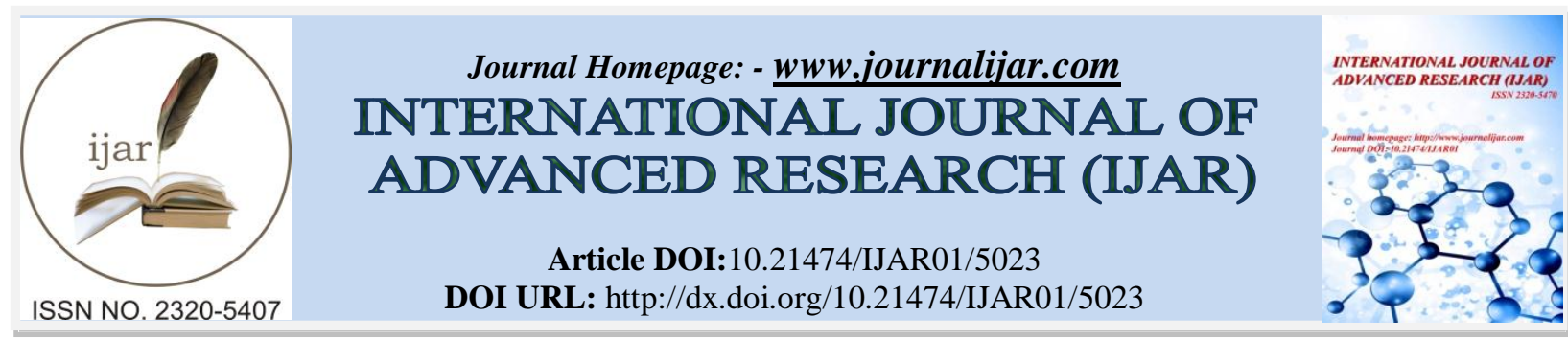

RESEARCH ARTICLE

\title{
RENAL AND ELECTROLYTE DYSFUNCTION ASSOCIATED WITH PLATINUM BASED
} CHEMOTHERAPY.

\section{Dr. Farhat Mustafa ${ }^{1}$, Dr. Manzoor Ahmad Bhat ${ }^{1}$ and Dr. M. Ashraf Bhat ${ }^{2}$.}

1. Resident, Department of Nephrology, Sher-i-Kashmir Institute of Medical Sciences.

2. Professor, Department of Nephrology, Sher-i- Kashmir Institute of Medical Sciences.

\section{Manuscript Info}

Manuscript History

Received: 29 May 2017

Final Accepted: 31 June 2017

Published: July 2017

\section{Abstract}

Background:- Nephrotoxicity is dose limiting side effect of platinum coordination complexes( cisplatin, carboplatin and oxaliplatin) which have revolutionised the treatment of many human cancers.

Objective:-To determine the renal and electrolyte abnormalities associated with platinum based chemotherapy.

Methods:- 70 newly diagnosed cancer patients who were put on combination chemotherapy were evaluated for various renal and electrolyte abnormalities during chemotherapy and were subsequently followed at six monthly intervals for a period of 18 months to ascertain any progression or reversibility in their renal functions.

Results :-Among the 70 patients studied, 42 patients received a cisplatin based chemotherapy; 7 received carboplatin based chemotherapy and 21 received oxaliplatin based chemotherapy. Cisplatin was the most nephrotoxic among the three drugs and nephrotoxicity was cumulative. There was successive rise in serum creatinine from $0.68 \pm 0.15 \mathrm{mg} / \mathrm{dl}$ to $1.14 \pm 0.53 \mathrm{mg} / \mathrm{dl}$ and successive fall in creatine clearance from $98.9 \pm 15.6 \mathrm{ml} / \mathrm{min}$ to $67.1 \pm 27.6 \mathrm{ml} / \mathrm{min}$ with each cycle of cisplatin. I6.7\% patients developed azotemia(creat> $1.5 \mathrm{mg} / \mathrm{dl}$ )after second cycle and $24.4 \%$ after third cycle of cisplatin. Nephrotoxicity was uncommon with carboplatin and oxaliplatin. There was persistence of deranged renal functions at followup even after stopping chemotherapy. Serum magnesium also fell sequentially from pre-treatment value of $0.9 \pm 0.2 \mathrm{mg} / \mathrm{dl}$ to $0.61 \pm 0.17 \mathrm{mg} / \mathrm{dl}$ at sixth cycle. Hypomagnesia persisted in 23 of 35 patients at follow up. Hypokalemia occurred more frequently than hypocalcemia in cisplatin group. Electrolyte abnormalities were less common with carboplatin and oxaliplatin.

Conclusions:- Cisplatin has cumulative nephrotoxicity which can persist even after the drug is stopped. Renal functions and electrolytes are to be closely and regularly monitored in patients on chemotherapy even when the drug has been stopped.

Copy Right, IJAR, 2017,. All rights reserved. 


\section{Introduction:-}

Nephrotoxicity is a dose limiting side effect of Platinum co-ordination complexes (cisplatin, carboplatin and oxaliplatin) which have revolutionized the treatment of many human cancers. Nephrotoxicity can manifest in the form of renal failure, azotemia and various electrolyte disturbances e.g. hypokalemia, hypomagnesemia and hypocalcemia.(Jon D et al., 1981, Rosoff A H et al .,1972). The nephrotoxicity may occur in as many as 50-75\% of patients receiving the drug and is apparently due to renal tubular injury. It can manifest as elevation in blood urea nitrogen and creatinine in 25-30\% of patients, progressive irrversible fall in creatinine clearance and renal magnesium wasting in as many as $60 \%$ of patients. Other electrolyte disturbances include hypocalcemia and hypokalemia. Proteinuria occurs in modest amounts as only tubular proteinuria occurs with sparing of glomeruli. (MeriellenDentino et al.,1978; Schilsky RL et al.,1979 ).

Nephrotoxicity commonly occurs with cisplatin and is rarely seen with carboplatin and oxaliplatin. Azotemia usually peaks by day 8 to 12 and recovery of renal functions requires three to four weeks, but recovery may be delayed for several months or may not occur at all. Renal toxicity associated with platinum is apparently permanent and careful monitoring of renal functions is essential to avoid this potentially serious consequence of treatment.(Lipmann AJ et al,) We studied the renal functions in 70 newly diagnosed cancer patients who were put on combination platinum based chemotherapy. Besides renal functions, electrolyte abnormalities were also studied and the patients were followed at six monthly interval for a period of 18 months.

\section{Materials And Methods:-}

70 new cancer patients who had not received chemotherapy previously and were put on platinum containing chemotherapy with normal creatinine clearance $>80 \mathrm{ml} / \mathrm{min}$ as estimated by Cockraft-Gault formula(CG) [(140age)body weight $/ 72 \mathrm{x}$ sr. creatinine (x0.85 for females)] were taken for the study. Complete clinical, biochemical and investigational data was reviewed before institution of chemotherapy. Informed verbal consent was obtained from each patient . 42 of 70 patients received cisplatin based combination chemotherapy. Cisplatin was used as a combination therapy with 5 Flouro- uracil in 13 patients, with etoposide in 9 patients, with taxol in 7 patients and with gemcitabine in 5 patients while adriamycin, cyclophosphamide and decarbazine were used in combination with cisplatin in single patient only. External beam radiotherapy in combination with cisplatin were employed in 5 patients only. 21 patients with colorectal cancers received oxaliplatin along with 5 flourouracil(5-FU) and calcium leucovorin (CLV) while 7 patients received carboplatin based chemotherapy.

\section{Methods of administration:-}

The cisplatin dose per course ranged from $50-100 \mathrm{mg} / \mathrm{sq} . \mathrm{m}$ given as a continous infusion in 5\% dextrose over $2-3$ hours followed by infusion of $100 \mathrm{ml}$ of $20 \%$ mannitol over $30 \mathrm{~min}$. Prehydration and premedication in the form of $500 \mathrm{ml}$ of $0.9 \% \mathrm{NS}$ with $24 \mathrm{mgs}$ of metaclopromide and $16 \mathrm{mgs}$ of dexamethasone was given over 1-2 hours. Posthydration was given along with potassium and magnesium supplements in all patients in the form of $500 \mathrm{ml}$ of $0.9 \%$ NS with 21 meq. of $\mathrm{KCl}$ and $1 \mathrm{gm}$ of $\mathrm{MgSo} 4$ over 3-4 hours. Carboplatin was administered as a continous infusion in 5\% dextrose over $1 / 2-1$ hour with prehydration same as for cisplatin but without posthydration. Oxaliplatin was given as a continous infision in 5\% dextrose over 3 hours preceded by premedication in the form of anti-emetics. This was followed by CLV infusion over 4 hours followed 2 hours later by $5 \mathrm{FU}$ intravenous push.

All patients received a standard evaluation before each course, including a history and physical examination, complete blood counts, serum electrolytes, biochemical screening battery including serum calcium, serum creatinine, serum urea, creatinine clearance as well as serum magnesium levels. 24 hour urinary protein was also determined. After completion of 6 courses of chemotherapy, all investigations were repeated at 6 monthly intervals at 6,12 and 18 months.

None of the patients received diuretics or nephrotoxic drugs or analgesics during the study period. All patients were normotensives, non-diabetic and had sterile urine. All had a thorough examination including urography and renography to identify any obstruction of urinary collecting duct.

Blood urea, serum creatinine, serum calcium, serum magnesium were estimated by standard procedures followed routinely in our clinical biochemistry laboratory. Potassium levels were measured on IL-Synthesis 45 analyser using ion selection method. 24 hour protein was quantitatively estimated by Biuret method and uric acid levels by Hitachi Analyser 912. 
Statistical Method:Data was described as averages and percentages. The intergroup comparison was done by students T test and Manwhitnui U test. The overall variables were analysed by analysis of variance ( ANOVA) and Kruskalwallis test.

\section{Observations And Results:-}

Among the 70 patients studied, 48 were males and 22 were females. 42 patients ( 27 males and 15 females) received a cisplatin based chemotherapy; 7 patients ( 3 males and 4 females) received carboplatin based chemotherapy and 21 patients (18 males and 3 females ) received oxaliplatin based chemotherapy.(Table 1)

21 patients with colorectal carcinoma were placed on oxaliplatin based chemotherapy; 4 patients with ovarian carcinoma ,2 with bronchogenic carcinoma and 1 with urothelial tumor were placed on carboplatin based chemotherapy while the rest of 42 patients of which 19 had bronchogenic carcinoma, 11 had gastro-intestinal tumor,4 had ovarian carcinoma, 3 had head and neck cancer, 3 had pancreatic cancer and one each with GB mass and urothelial tumor were on cisplatin based combination regimen.

All the patients were subjected to 6 cycles of chemotherapy after every 3-4 weeks with investigations being done one day prior to each cycle to assess the effect of previous cycle on various parameters. The patients were followed six monthly for a total of 18 months. 2 patients on cisplatin based chemotherapy lost follow up during the study period. 1 patient on carboplatin based chemotherapy died after completing 6 cycles while 2 patients on oxaliplatin based chemotherapy died at followup.(Table 2)

Cisplatinum was the most nephrotoxic among the three drugs and it was observed that cisplatin nephrotoxicity is dose - dependent and cumulative.A significant and transient elevation of blood urea and creatinine levels with progressive fall in creatinine clearance is observed in most patients after a single dose and cumulatively after subsequent cycles and can last in some patients for more than two years even after the chemotherapy has been stopped.

There was a progressive rise in urea concentration from a pretreatment mean of $26.7 \pm 9.0 \mathrm{mg} / \mathrm{dl}$ to $49.8 \pm 16.0$ $\mathrm{mg} / \mathrm{dl}$ at $6^{\text {th }}$ cycle for cisplatin group. At 6,12 and 18 months, the mean value was $35.8 \pm 10.9 \mathrm{mg} / \mathrm{dl}, 34.4 \pm 8.3$ $\mathrm{mg} / \mathrm{dl}, 32.9 \pm 7.6 \mathrm{mg} / \mathrm{dl}$ respectively. Similar change was observed with carboplatin and oxaliplatin also but the change was not as significant as with cisplatin.(Fig1)

The mean creatinine increased from a baseline of $0.68 \pm 0.15 \mathrm{mg} / \mathrm{dl}$ to $1.07 \pm 0.6 \mathrm{mg} / \mathrm{dl}$ after second cycle and thereafter increased to $1.15 \pm 0.53$ at fourth cycle and remained stable till sixth cycle. There was improvement in renal functions at followup with values at 6,12 and 18 months remaining constant. No significant worsening was seen with carboplatin and oxaliplatin. (Fig 2)

A similar trend was observed with creatinine clearance which was calculated by Cockcroft-Gault formula. With each successive course of chemotherapy, the creatinine clearance also fell. ( Table: 3) The mean creatinine clearance for the cisplatin group fell from $98.9 \pm 15.6 \mathrm{ml} / \mathrm{min}$ to $71.5 \pm 27 \mathrm{ml} / \mathrm{min}$ at third cycle and subsequently to $67.1 \pm 27.6 \mathrm{ml} / \mathrm{min}$ by the end of six cycles. At followup at 6,12 and $18 \mathrm{months}$, the mean creatinine clearance was $76.5 \pm 27.6 \mathrm{ml} / \mathrm{min}, 76.5 \pm 28.4$ and $77.4 \pm 27.8 \mathrm{ml} / \mathrm{min}$ respectively. The mean creatinine clearance for the carboplatin and oxaliplatin group did not change significantly. (Fig 3)

Overall results of creatinine clearance revealed $61.9 \%$ cases of renal failure occured in cisplatin group and $14.3 \%$ cases in carboplatin and $0.5 \%$ in oxaliplatin group.(Table: 4) No significant change was observed in serum uric acid serum albumin and 24 hour urinay protein in the study group.

There was a sequential fall in the serum magnesium, calcium and poatassium levels during therapy and hypomagnesemia persisted during followup. Hypomagnesemia( normal range was taken as $0.8-1.2 \mathrm{mg} / \mathrm{dl}$ ) was more common and more severe with cisplatin than with carboplatin and oxaliplatin. Intergroup comparison and overall comparison was significant after the institution of chemotherapy with $\mathrm{a}<0.05$ after third cycle and $\mathrm{b}<0.05$ and $\mathrm{F}<$ 0.05 after second and third cycle onwards respectively.

87.5\% patients on cisplatin developed hypomagnesemia at sixth cycle and hypomagnesemia persisted in $80-85 \%$ patients at followup. In carboplatin group, hypomagnesemia was seen in $14.3 \%$ cases at sixth cycle and persisted in $16.7 \%$ cases on followup. In oxaliplatin group, $25 \%$ patients developed hypomagnesemia and persisted in $15 \%$ on 
followup.( Fig 4)There was a fall in serum calcium and potassium levels with each successive course of chemotherapy which was more often associated with cisplatin. Hypokalemia( normal range 3.5-5.3 mg/dl) was observed in $80 \%$ patients on cisplatin at sixth cycle. $28.6 \%$ patients on carboplatin and only $5 \%$ patients on oxaliplatin had hypokalemia at sixth cycle. On follow up , 22 patients persisted with hypokalemia; out of which, 21 had received cisplatin and one had received carboplatin while none had received oxaliplatin. It was observed that hypocalcemia and hypokalemia occurred in the presence of hypomagnesemia.(Figs 5 and Figs 6)

Although electrolyte supplements were given with each cycle, still dyselectrolytemis in the form of hypomagnesemia, hypocalcemia and hypokalemia occurred in the study population. Thus electrolytes should be closely monitored and replaced in each cycle during chemotherapy.

Table 1:- Gender distribution of patients.

\begin{tabular}{|c|c|c|c|c|c|c|c|}
\hline \multicolumn{8}{|c|}{ Chemotherapy Regimen } \\
\hline \multirow[t]{2}{*}{ Gender } & \multicolumn{2}{|c|}{ Cisplatin } & \multicolumn{2}{|c|}{ Carboplatin } & \multicolumn{2}{|c|}{ Oxaliplatin } & \multirow[t]{2}{*}{$\mathrm{p}$ value } \\
\hline & $\mathrm{n}$ & $\%$ & $\mathrm{~N}$ & $\%$ & $\mathrm{~N}$ & $\%$ & \\
\hline Male & 27 & 64.3 & 3 & 42.9 & 18 & 85.7 & \multirow[t]{2}{*}{0.071} \\
\hline Female & 15 & 35.7 & 4 & 57.1 & 3 & 14.3 & \\
\hline
\end{tabular}

Table 2:- Final outcome.

\begin{tabular}{|l|l|l|l|l|l|l|l|}
\hline & & \multicolumn{2}{|l|}{ CISPLATIN } & \multicolumn{2}{l|}{ CARBOPLATIN } & \multicolumn{2}{l|}{ OXALIPLATIN } \\
\hline \multirow{2}{*}{ Final Outcome } & Surviving & 40 & 95.2 & 6 & 85.7 & 19 & 90.5 \\
\cline { 2 - 8 } & Died & & & 1 & 14.3 & 2 & 9.5 \\
\cline { 2 - 8 } & Lost to Follow Up & 2 & 4.8 & & & & \\
\hline
\end{tabular}

Table 3:- Comparison of creatinine clearance over the study period.

\begin{tabular}{|c|c|c|c|c|c|c|c|c|c|c|c|c|c|}
\hline \multirow{2}{*}{$\begin{array}{l}\text { Creatinine } \\
\text { Clearance }\end{array}$} & \multicolumn{3}{|c|}{ Cisplatin } & \multicolumn{3}{|c|}{ Carboplatin } & \multicolumn{3}{|c|}{ Oxaliplatin } & \multirow[t]{2}{*}{ A } & \multirow[t]{2}{*}{ B } & \multirow[t]{2}{*}{$\mathrm{C}$} & \multirow[t]{2}{*}{$\mathrm{F}$} \\
\hline & $\begin{array}{l}\mathrm{mi} \\
\mathrm{n}\end{array}$ & $\max$ & $\begin{array}{l}\text { Mean } \pm \\
\text { SD }\end{array}$ & $\begin{array}{l}\mathrm{Mi} \\
\mathrm{n}\end{array}$ & $\max$ & $\begin{array}{l}\text { Mean } \pm \\
\text { SD }\end{array}$ & $\begin{array}{l}\mathrm{mi} \\
\mathrm{n}\end{array}$ & $\max$ & $\begin{array}{l}\text { Mean } \pm S \\
\text { D }\end{array}$ & & & & \\
\hline Baseline & $\begin{array}{l}80 . \\
5\end{array}$ & $\begin{array}{l}131 \\
.9 \\
\end{array}$ & $\begin{array}{l}9689 \pm 1 \\
5.6\end{array}$ & $\begin{array}{l}81 . \\
7\end{array}$ & $\begin{array}{l}122 \\
.0\end{array}$ & $\begin{array}{l}99.7 \pm 4 \\
6.2\end{array}$ & $\begin{array}{l}80 . \\
1\end{array}$ & $\begin{array}{l}131 \\
.1 \\
\end{array}$ & $\begin{array}{l}104.3 \pm 1 \\
6.9\end{array}$ & $\begin{array}{l}0.8 \\
60 \\
\end{array}$ & $\begin{array}{l}0.2 \\
13 \\
\end{array}$ & $\begin{array}{l}0.3 \\
53 \\
\end{array}$ & $\begin{array}{l}0.4 \\
12 \\
\end{array}$ \\
\hline Ist Cycle & $\begin{array}{l}80 . \\
5\end{array}$ & $\begin{array}{l}131 \\
.9\end{array}$ & $\begin{array}{l}98.9 \pm 15 \\
.6\end{array}$ & $\begin{array}{l}81 . \\
7\end{array}$ & $\begin{array}{l}122 \\
.0\end{array}$ & $\begin{array}{l}99.7 \pm 4 \\
6.2\end{array}$ & $\begin{array}{l}80 . \\
1\end{array}$ & $\begin{array}{l}131 \\
.1\end{array}$ & $\begin{array}{l}104.3 \pm 1 \\
6.9\end{array}$ & $\begin{array}{l}0.8 \\
60\end{array}$ & $\begin{array}{l}0.2 \\
13\end{array}$ & $\begin{array}{l}0.3 \\
53\end{array}$ & $\begin{array}{l}0.4 \\
12\end{array}$ \\
\hline 2nd Cycle & $\begin{array}{l}40 . \\
8\end{array}$ & $\begin{array}{l}167 \\
.6 \\
\end{array}$ & $\begin{array}{l}85.9 \pm 28 \\
.5\end{array}$ & $\begin{array}{l}81 . \\
7\end{array}$ & $\begin{array}{l}138 \\
.9 \\
\end{array}$ & $\begin{array}{l}93.6 \pm 2 \\
0.1\end{array}$ & $\begin{array}{l}81 . \\
8\end{array}$ & $\begin{array}{l}186 \\
.7\end{array}$ & $\begin{array}{l}108.1 \pm 3 \\
0.7\end{array}$ & $\begin{array}{l}0.5 \\
09 \\
\end{array}$ & $\begin{array}{l}0.0 \\
05\end{array}$ & $\begin{array}{l}0.2 \\
50\end{array}$ & $\begin{array}{l}0.0 \\
19 \\
\end{array}$ \\
\hline 3rd Cycle & $\begin{array}{l}17 . \\
7\end{array}$ & $\begin{array}{l}119 \\
.7 \\
\end{array}$ & $\begin{array}{l}71.5 \pm 27 \\
.0 \\
\end{array}$ & $\begin{array}{l}81 . \\
7 \\
\end{array}$ & $\begin{array}{l}138 \\
.9 \\
\end{array}$ & $\begin{array}{l}93.6 \pm 2 \\
0.1 \\
\end{array}$ & $\begin{array}{l}81 . \\
8\end{array}$ & $\begin{array}{l}176 \\
.6 \\
\end{array}$ & $\begin{array}{l}104.5 \pm 2 \\
7.8 \\
\end{array}$ & $\begin{array}{l}0.0 \\
48 \\
\end{array}$ & $\begin{array}{l}0.0 \\
00\end{array}$ & $\begin{array}{l}0.4 \\
04\end{array}$ & $\begin{array}{l}0.0 \\
00\end{array}$ \\
\hline 4th Cycle & 8.1 & $\begin{array}{l}119 \\
.7 \\
\end{array}$ & $\begin{array}{l}65.7 \pm 27 \\
.0\end{array}$ & $\begin{array}{l}81 . \\
2\end{array}$ & $\begin{array}{l}108 \\
.3 \\
\end{array}$ & $\begin{array}{l}91.3 \pm 1 \\
1.1 \\
\end{array}$ & $\begin{array}{l}80 . \\
1 \\
\end{array}$ & $\begin{array}{l}175 \\
.9 \\
\end{array}$ & $\begin{array}{l}109.0 \pm 3 \\
1.6\end{array}$ & $\begin{array}{l}0.0 \\
01\end{array}$ & $\begin{array}{l}0.0 \\
00\end{array}$ & $\begin{array}{l}0.9 \\
40 \\
\end{array}$ & $\begin{array}{l}0.0 \\
00 \\
\end{array}$ \\
\hline 5th Cycle & $\begin{array}{l}30 . \\
3\end{array}$ & $\begin{array}{l}119 \\
.7 \\
\end{array}$ & $\begin{array}{l}67.2 \pm 26 \\
.4\end{array}$ & $\begin{array}{l}82 . \\
3 \\
\end{array}$ & $\begin{array}{l}96 . \\
7\end{array}$ & $\begin{array}{l}90.0 \pm 5 . \\
1\end{array}$ & $\begin{array}{l}78 . \\
7\end{array}$ & $\begin{array}{l}169 \\
.3\end{array}$ & $\begin{array}{l}108.4 \pm 2 \\
6.7\end{array}$ & $\begin{array}{l}0.0 \\
02\end{array}$ & $\begin{array}{l}0.0 \\
00\end{array}$ & $\begin{array}{l}0.6 \\
75\end{array}$ & $\begin{array}{l}0.0 \\
00\end{array}$ \\
\hline 6th Cycle & $\begin{array}{l}30 . \\
3\end{array}$ & $\begin{array}{l}119 \\
.7\end{array}$ & $\begin{array}{l}67.1 \pm 27 \\
.6\end{array}$ & $\begin{array}{l}27 . \\
1\end{array}$ & $\begin{array}{l}138 \\
.9\end{array}$ & $\begin{array}{l}89.3 \pm 3 \\
3.0\end{array}$ & $\begin{array}{l}81 . \\
3\end{array}$ & $\begin{array}{l}170 \\
.3\end{array}$ & $\begin{array}{l}102.5 \pm 2 \\
2.3\end{array}$ & $\begin{array}{l}0.0 \\
45\end{array}$ & $\begin{array}{l}0.0 \\
00\end{array}$ & $\begin{array}{l}0.3 \\
29\end{array}$ & $\begin{array}{l}0.0 \\
00\end{array}$ \\
\hline 6 month FU & $\begin{array}{l}32 . \\
9\end{array}$ & $\begin{array}{l}150 \\
.7 \\
\end{array}$ & $\begin{array}{l}76.5 \pm 27 \\
.6\end{array}$ & $\begin{array}{l}81 . \\
2\end{array}$ & $\begin{array}{l}104 \\
.1\end{array}$ & $\begin{array}{l}90.7 \pm 8 . \\
1\end{array}$ & $\begin{array}{l}80 . \\
6\end{array}$ & $\begin{array}{l}150 \\
.8\end{array}$ & $\begin{array}{l}98.3 \pm 22 \\
.9\end{array}$ & $\begin{array}{l}0.5 \\
91 \\
\end{array}$ & $\begin{array}{l}0.0 \\
03\end{array}$ & $\begin{array}{l}0.1 \\
87 \\
\end{array}$ & $\begin{array}{l}0.0 \\
10 \\
\end{array}$ \\
\hline 12 month FU & $\begin{array}{l}32 . \\
9\end{array}$ & $\begin{array}{l}144 \\
.8 \\
\end{array}$ & $\begin{array}{l}76.5 \pm 28 \\
.4\end{array}$ & $\begin{array}{l}82 . \\
6 \\
\end{array}$ & $\begin{array}{l}103 \\
.8\end{array}$ & $\begin{array}{l}92.7 \pm 8 . \\
9\end{array}$ & $\begin{array}{l}81 . \\
0\end{array}$ & $\begin{array}{l}142 \\
.5 \\
\end{array}$ & $\begin{array}{l}101.0 \pm 1 \\
6.7\end{array}$ & $\begin{array}{l}0.3 \\
68 \\
\end{array}$ & $\begin{array}{l}0.0 \\
00 \\
\end{array}$ & $\begin{array}{l}0.1 \\
92 \\
\end{array}$ & $\begin{array}{l}0.0 \\
02 \\
\end{array}$ \\
\hline 18 month FU & $\begin{array}{l}34 . \\
7\end{array}$ & $\begin{array}{l}144 \\
.8 \\
\end{array}$ & $\begin{array}{l}77.4 \pm 27 \\
.8\end{array}$ & $\begin{array}{l}82 . \\
6\end{array}$ & $\begin{array}{l}113 \\
.1\end{array}$ & $\begin{array}{l}95.0 \pm 1 \\
1.1\end{array}$ & $\begin{array}{l}84 . \\
4\end{array}$ & $\begin{array}{l}150 \\
.8 \\
\end{array}$ & $\begin{array}{l}105.8 \pm 1 \\
9.2\end{array}$ & $\begin{array}{l}0.3 \\
61 \\
\end{array}$ & $\begin{array}{l}0.0 \\
00 \\
\end{array}$ & $\begin{array}{l}0.1 \\
09\end{array}$ & $\begin{array}{l}0.0 \\
00 \\
\end{array}$ \\
\hline
\end{tabular}

$\mathrm{a}=$ cisplatin and carboplatin, $\mathrm{b}=$ cisplatin and oxaliplatin and $\mathrm{c}=$ carboplatin and oxaliplatin, $\mathrm{F}=($ analysis of variance $)$ overall comparison 
Table4:- Follow up results of creatinine clearance.

\begin{tabular}{|c|c|c|c|c|c|c|c|c|}
\hline Chemotherapy Regimen \\
\hline & \multicolumn{2}{|c|}{ Cisplatin } & \multicolumn{2}{|c|}{ Carboplatin } & \multicolumn{2}{|c|}{ Oxaliplatin } & \multicolumn{2}{|c|}{ Total } \\
\cline { 2 - 10 } Overall Follow Up Results of Creatinine Clearance & $\mathrm{n}$ & $\%$ & $\mathrm{n}$ & $\%$ & $\mathrm{n}$ & $\%$ & $\mathrm{n}$ & $\%$ \\
\hline Normal & 16 & 38.1 & 6 & 85.7 & 20 & 95.2 & 42 & 60 \\
\hline Abnormal & 26 & 61.9 & 1 & 14.3 & 1 & 0.5 & 28 & 40 \\
\hline Total & 42 & 100.0 & 7 & 100.0 & 21 & 100.0 & 70 & 100.0 \\
\hline
\end{tabular}

Fig 1:-comparison of urea across drug regimens over the study period.

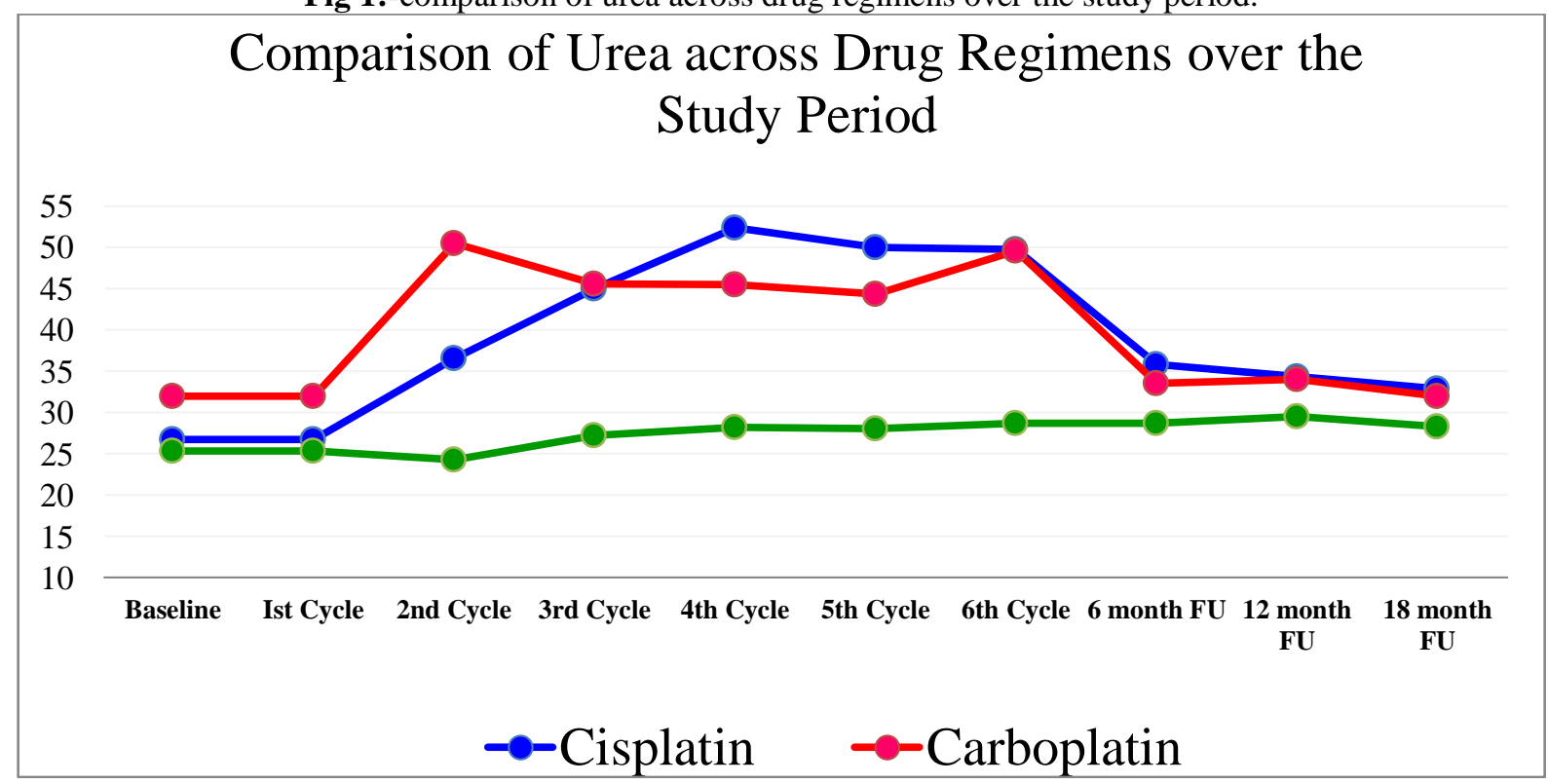

Fig 2:- comparison of creatinine across drug regimen over the study period.

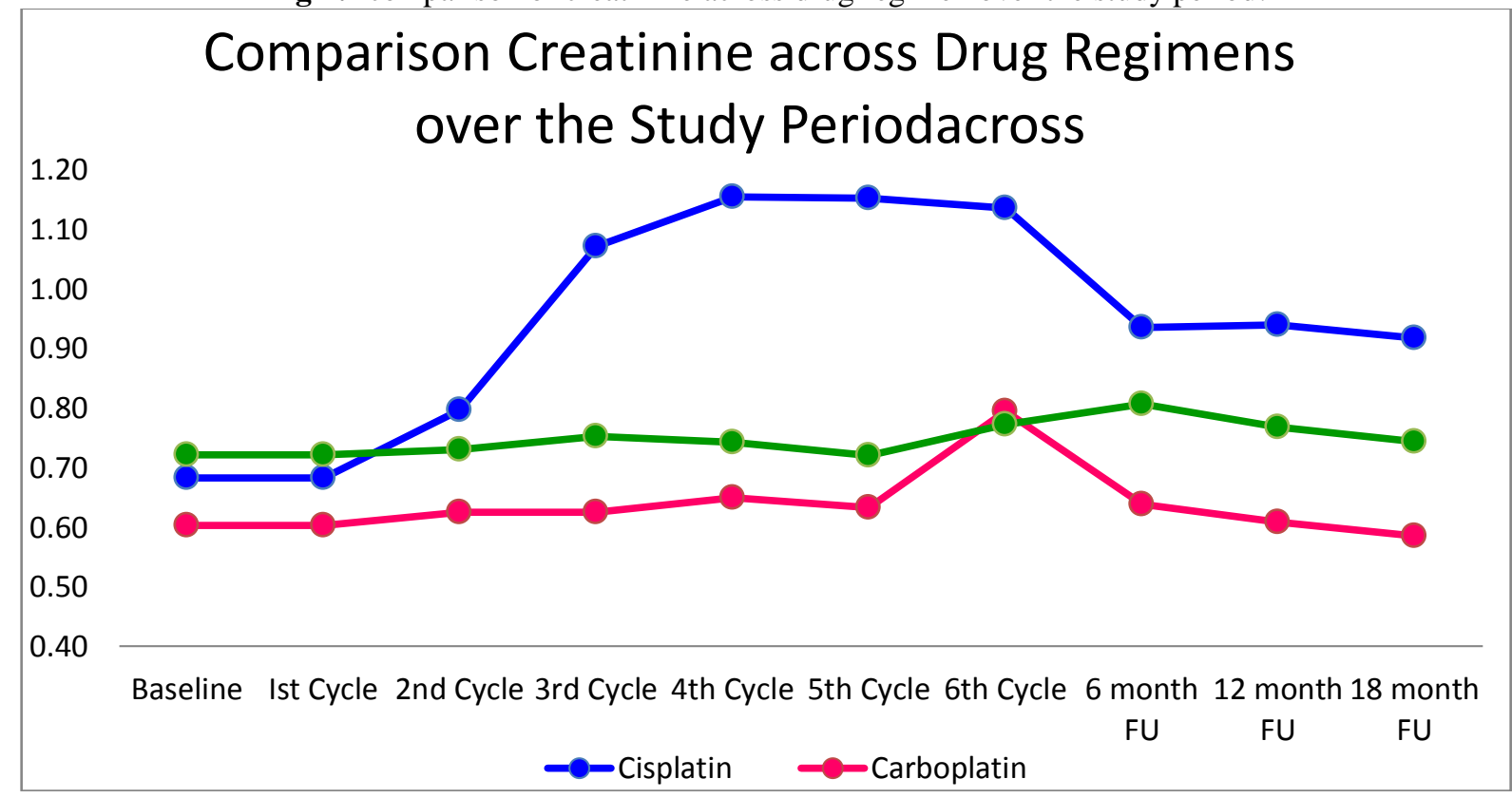


Fig 3:- Comparison of creatinine clearance over the study period.

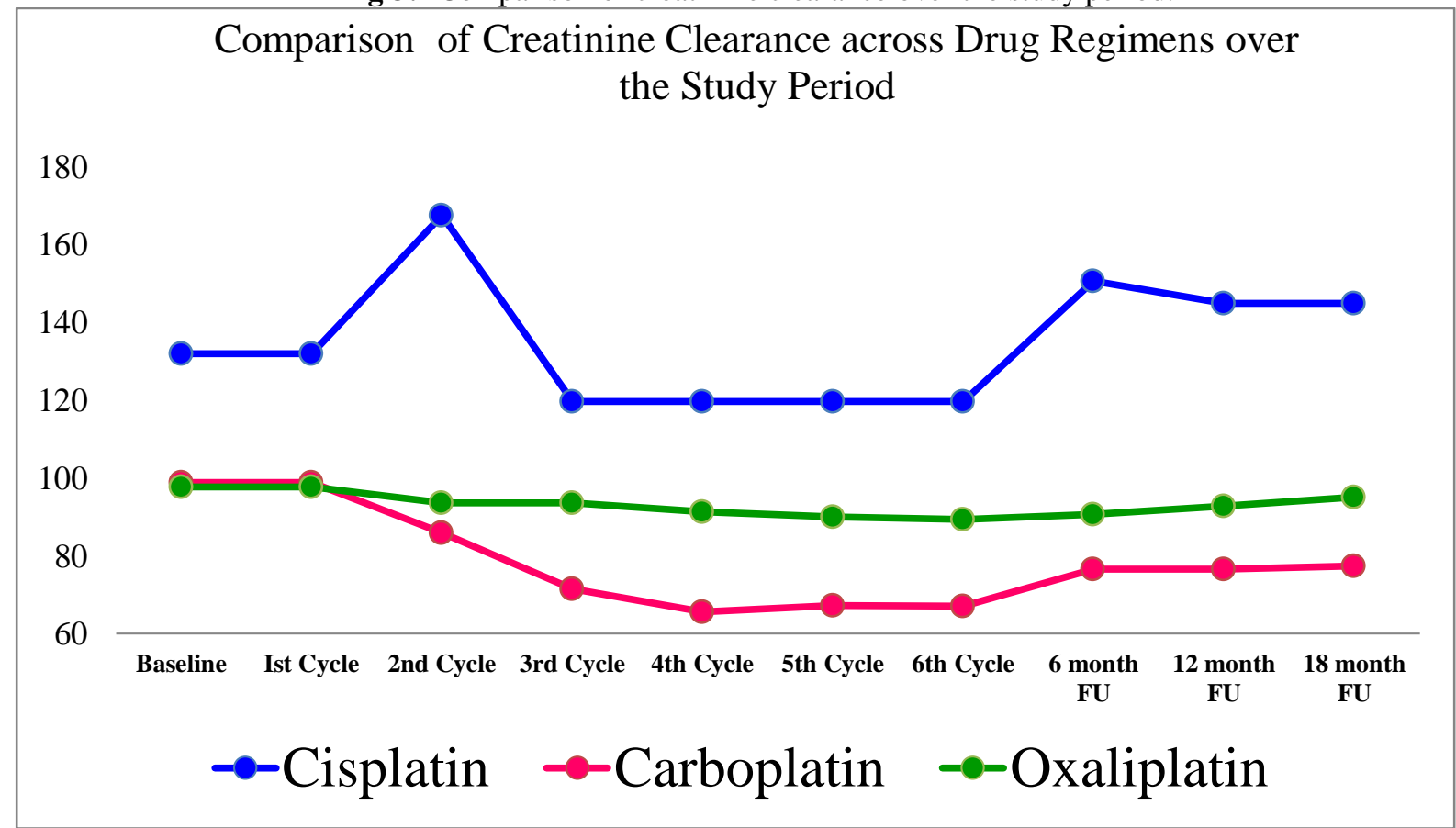

Fig4:- Comparison of magnesium across drug regimens over the study period.

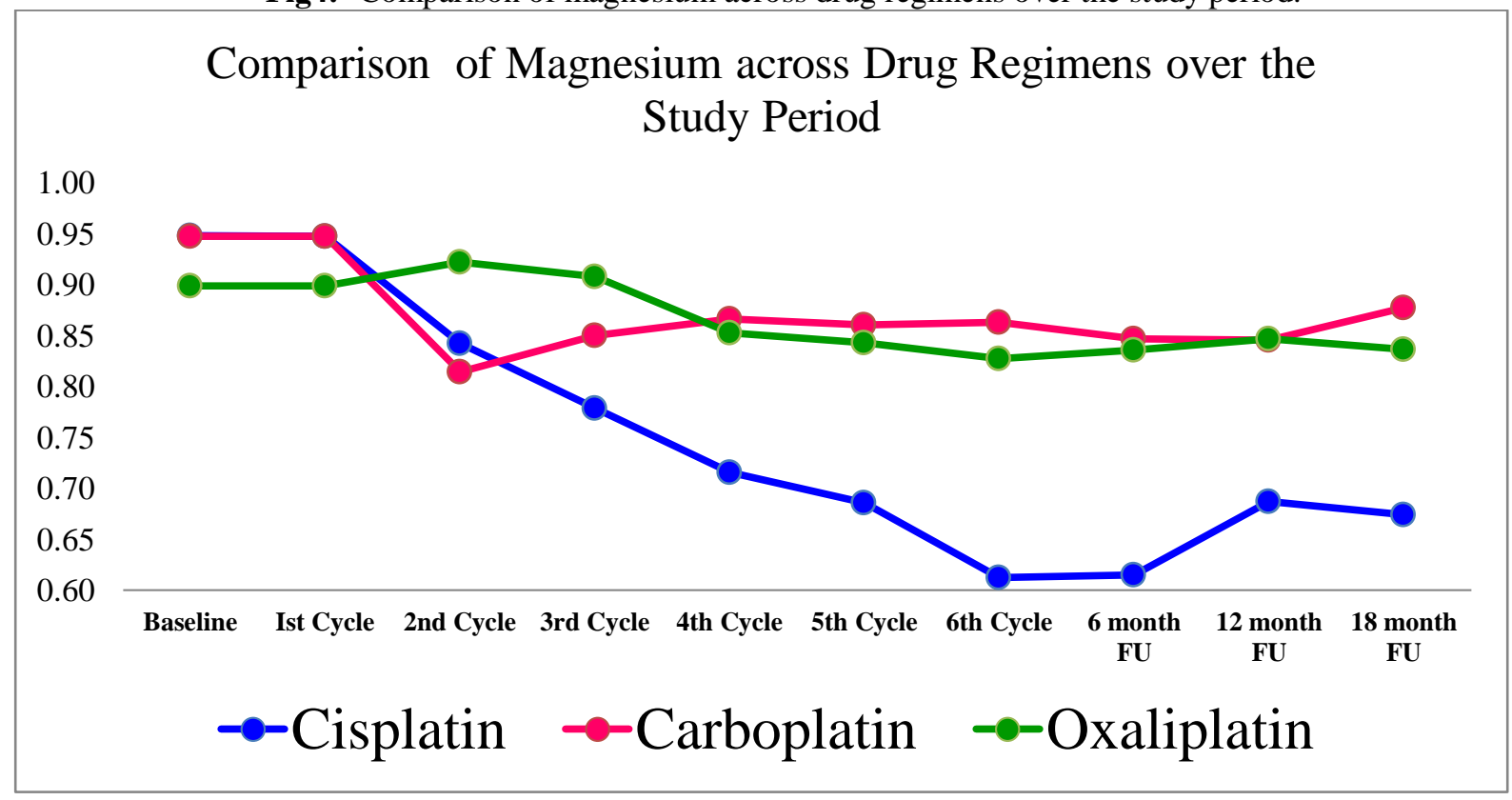


Fig 5:- Comparison of calcium across drug regimens over the study period.

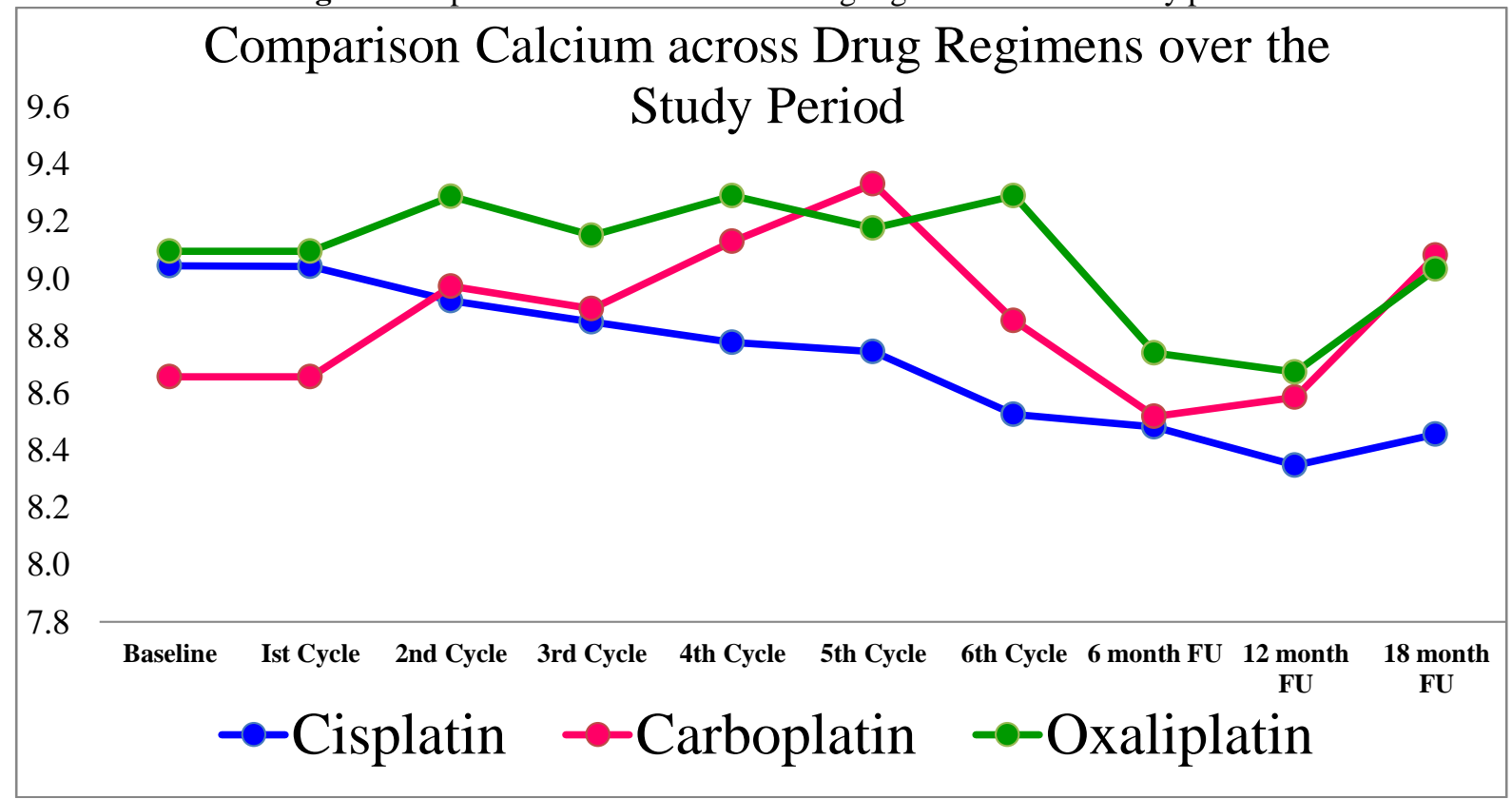

Fig6:- Comparison of potassium across the drug regimen over the study period.

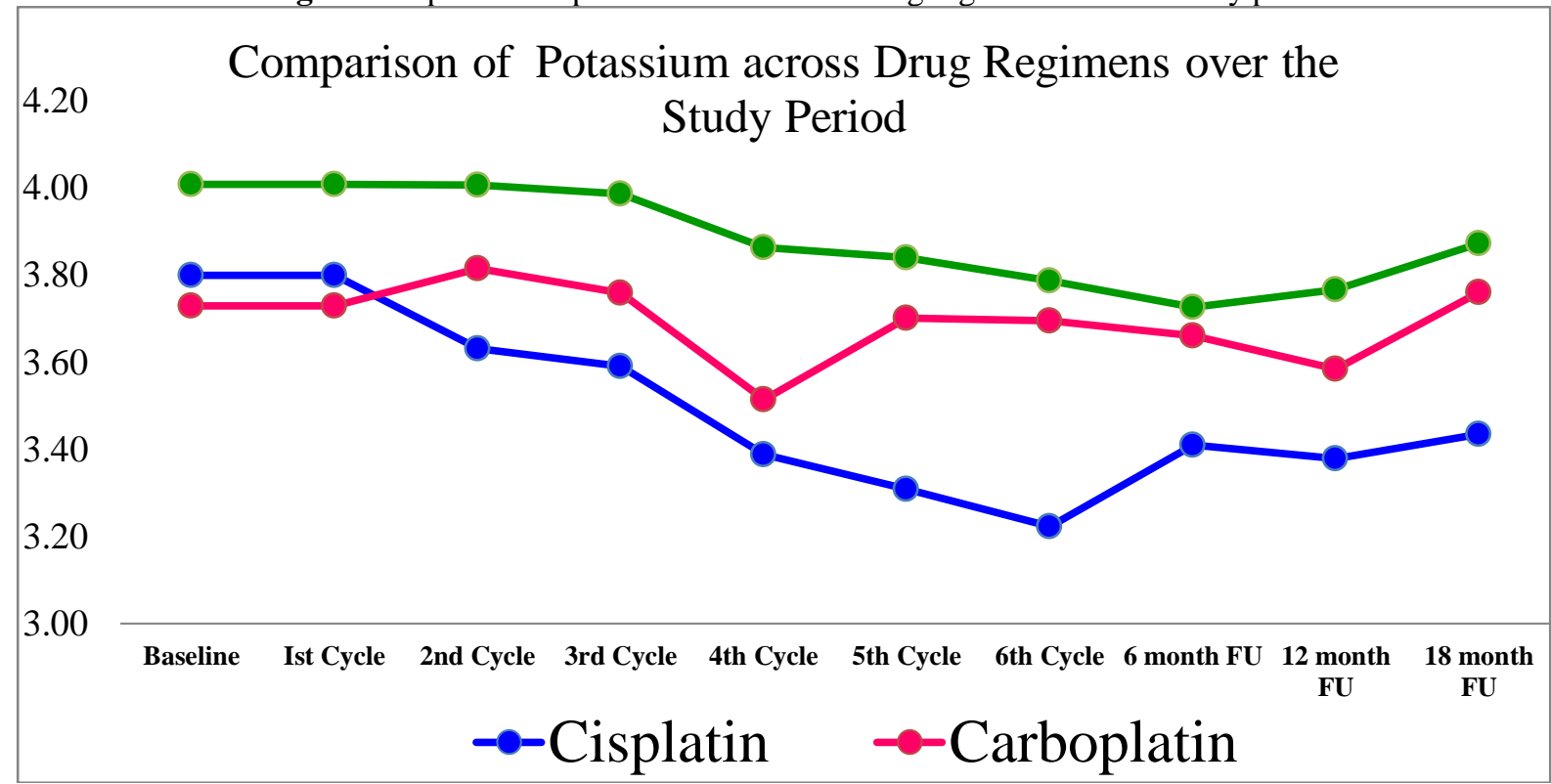

\section{Discussion:-}

Cisplatin, a platinum coordinatio compound remains a major antineoplastic drug for the treatment of solid tumors. Its chief dose limiting side effect is nephrotoxicity, which evolves slowly and predictably after initial and repeated exposure. The kidney accumulates cisplatin to a higher degree than other organs perhaps via mediated transport. Functionally, reduced renal perfusion and a concentrating defect characterize its nephrotoxicity, whereas morphologically necrosis of the terminal portion of the proximal tubule and apoptosis predominantly in the distal nephron characterize its effects on cell fate. (Sliejfer Meijer.,1983, Lipmann AJ., 1973 )Cisplatin induced renal toxicity and renal effects of the platinum analogues carboplatin and oxaliplatin is reviewed in our study which was conducted at SKIMS Hospital as the use of these drugs has increased considerably since past few years in Kashmir Valley with the increase in the incidence of various malignancies. 
The results of this follow-up study confirm previous reports of the frequency, nature and severity of cisplatin nephrotoxicity leading to clinically important reductions in GFR and serum magnesium concentration. These adverse effects occured despite the use of pre- and post- hydration protocols, which reduce the frequency and severity of nephrotoxicity, rather than abolish it altogether. Cisplatin nephrotoxicity is dose - dependent and cumulative.(Jon D et al.,Schilsky RL.,1982)

A significant and transient elevation of blood urea and creatinine levels is observed in most patients after a single dose and cumulatively after subsequent cycles and can last in some patients for mor than two years. . In our study, cisplatin was the most nephrotoxic with 26 of 42 patients $(61.9 \%)$ getting fall in creatinine clearance of $<80 \mathrm{ml} / \mathrm{min}$ at some time during chemotherapy. Only a single patient on carboplatin out of $7(14.3 \%)$ and a single patient on oxaliplatin out of 21 patients $(0.05 \%)$ were found to have a creatinine clearance $<80 \mathrm{ml} / \mathrm{min}$. In total, $40 \%$ cases had fall in creatinine clearance at some point during chemotherapy. These findings were consistent with the results obtained by Lippmann et., 1973 who observed 50\% reduction in renal functions in each of 16 patients treated with cisplatin. The findings were also consistent with those found by Rossof AH., 1972 who found cisplatin nephrotoxicity was cumulative in humans.

Azotemia ( sr. creat> $1.5 \mathrm{mg} / \mathrm{dl}$ ) was commonly seen with cisplatin ( $24.4 \%$ ). Two of the patients persisted with creatinine $>1.5 \mathrm{mg} / \mathrm{dl}$ even on follow-up at 18 months. These findings were consistent with the results obtained by Dentino et al.,1978. There was only a single patient on carboplatin chemotherapy who developed impairment in renal functions (14.3\%). The results were not consistent with those obtained by Robert F. Ozols., 1987 who found considerable loss of renal functions with multiple courses of carboplatn unlike our study. However, the results were consistent with Sleijfer Meijer.,1989 who found only 19\% fall in renal functions. Nephrotoxicity was rarely seen with oxaliplatin and occurs mainly secondary to dehydration. Cases of acute nephrotoxicity unrelated to dehydration have been reported. (David P Ryan et al.,2006, S Sunder et al .,2004)

The apparent partial reversibility in glomerular impairment observed in our study were consistent with those obtained by Dentino et al., 1978 and Brock ., 1991. Nephrotoxicity due to carboplatin was seen in $14.3 \%$ cases. These findings were consistent with those obtained by Mason et al.,1991 who found 21\% patients had fall in 10\% or greater in renal functions.

There was no significant changes in serum albumin and urinary excretion of proteins induced by platinum coordination complexes in our study; a finding consistent with that obtained by Dentino et al., 1978. Hyperuricemia occurred during chemotherapy but later settled.

Cisplatin is notorious in causing renal tubular dysfunction which manifests as electrolyte disturbances due to increased urinary losses. Hypomagnesemia $(<0.8 / \mathrm{dl})$ was seen in $87.5 \%$ patients on cisplatin chemotherapy, $28.6 \%$ patients on carboplatin chemotherapy and $25 \%$ patients on oxaliplatin chemotherapy despite magnesium replacement in our study. Hypomagnesemia persisted in $61.5 \%$ patients at 18 months after stopping cisplatinum. The incidence of hypomagnesemia increased with cumulative cisplatin (Buckley J E., 1984,Bell D R ., 1985, PM Netten.,1990) which was also seen in our study. The results were similar to those obtained by Schilsky et al .,1982, Lam M.,1986) Hypomagnesemia does not occur frequently with carboplatin(10-15\%)(D T Sliejfer., 1989, M D Mason., 1991., Ursula A., 2009). Higher incidence in our study was due to small sample size (7) of the studied patients in carboplatin group. A close association have been found with oxaliplatin induced hypomagnesemia and peripheral nephropathy .(David P Ryan., 2006, Ssunder., 2004)

Renal electrolyte disturbances frequently occur with platinum based chemotherapy despite corrective measures and as such should be regularly monitored in patients on chemotherapy. The apparent partial reversibility of glomerular but not tubular toxicity is consistent with the observation of Brock et al., 1991 and is an important finding in view of continued use of platinum coordination complexes in various combination chemotherapy protocols.

In conclusion, despite the pre- and post- hydration protocols and mannitol induced diuresis employed in our study as preventive measures, nephrotoxicity still occurred though at lower frequency and less severity. Extra care should be taken while administering chemotherapy and electrolytes should be closely monitored and replaced whenever necessary. 


\section{References:-}

1. Bell DR, Woods RL, Levi JA. Cis-Diamminedichloroplatinum induced hypomagnesemia and renal magnesium wasting. Eur J Caner and Clin Oncology. 1985Mar; 21(3): 287-90

2. Brock PR, Koliouskas DE, Barratt TM, Yeomans E and Pritchard J (1991). Partial reversibility of cisplatin nephrotoxicity in children . J Pdiatr 118: 531-533

3. Buckley JE, Clark VL, Meyer TJ, Pearlman NW. Hypomagnesemia after combination chemotherapy. Arch of Intrn Medicine, 1984Dec; 144(12): 2347-8.

4. David P. Ryan, et al. Phase 1 and 2 study of preoperative oxaliplatin, Fluorouracil and external beam radiation therapy in patients with locally advanced rectal cancer. Journal of clinical oncology. Vol 24 (16) June 2006: 2557-2562

5. Jon D. Blachley M.D, Julian B. HillM. D. Renal and electrolyte disturbances associated with cisplatin. Annals of internal medicine 1981; 95:628-632

6. Lam M, Adelstein DJ. Hypomagnesemia and renal magnesium wasting in patients treated with cisplatin.Am J Kidney Disease. 1986,Sep; 8(3): 164-9.

7. Lipmann A J, Helson C, Helson L, Krakoff I H. Clinical trials ofCDDP. Cancer Chemother Rep 1973: 57: 191200.

8. M.D Mason, J. Nicholls, and A. Horwich. The effect of carboplatin on renal function in patients with metastatic germ cell tumors. Br. J. Cancer , 1991 Apr. 63 (4):630-633

9. MariellenDentino M.D, Friedrich C. Luft M.D, Moo Nahm Yum M.D, Stephen D. Williams M.D and Lawrence H. Einhorn M.D . Long term effect of Cis- diamminedichloride platinum on renal function and structure in man. Cancer 41: 1274-1281, 1978.

10. P. M. Netten, P.H.M. de Mulder, A.G. Theeuwes, J.L. Willems, B.E.M Kohler and DJ.Th. Wagener. Intravenous magnesium supplementation during cisdiamminedichloroplatinum administration prevents hypomagnesemia. Annals of Oncology 1: 369-372, 1990.

11. Richard L Schilsky and Tom Anderson: Hypomagnesemia and renal magnesium wasting in patients receiving cisplatin. Annals of Internal Medicine. 90: 929-931;1979.

12. Robert F. Ozols, YechiamOstachega, Gregory Curt and Robert C. Young. High dose carboplatin in refractory ovarian cancer patients. Journal of Clinical Oncology, vol. 5 no.2(feb) 1987, 197-201

13. Rossof A H, Slayton R E, Perlia C P. Preliminary clinical experience with CDDP(2). Cancer 1972 : 30 : 14511456

14. SchilskyRL, Barlock A, Ozols RF. Persistent hypomagnesemia following cisplatin chemotherapy for testicular cancer. Cancer Treat Rep. 1982 sep; 66 (9):1767-9

15. Sitze Meijer MD, Dirk TH. Sliejfer MD, Nanno H. Mulder MD, Wim J. Sluiter PhD, Jan Marrink PhD, HemenScraffordtKoops MD, Theo M. Brouwers MD, Jan Oldhoff MD, Gjalt K Van DER hem MD and EnnoMandema MD. Effects of combination chemotherapy with cisplatinum on renal functions in patients with non-seminomatous testicular cancer. Cancer 51: 2035-2040, 1983

16. S. Sunder, R.P Symonds et al. Phase (2) trials of oxaliplatin and leucovorin combination in epithelial ovarian carcinoma within two years of platinum based therapy. Gynaecol Oncology 2004. 94.2; 502-508.

17. Sleijfer D. T., E.F. Smit, S. Meijer, N.H.Mulder\& P.E. Postmus.

18. Acute and cumulative effects of carboplatin on renal function. B. J. Cancer. 1989, July; 60(1): 116-120.

19. Ursula A, Matulonis, Karen J, Kreg et al. Phase (2) prospective study of paclitaxol and carboplatin in older patients with newly diagnosed Mullerian tumors. GynaecolOncol. Vol. 112 (2) Feb. 2009. 394-399. 